[Agr. Biol. Chem., Vol. 25, No. 6, p. 479 486, 1961]

\title{
The Relationship between Antigenic Compounds Produced by Sweet Potato in Response to Black Rot Infection and the Magnitude of Disease Resistance*
}

\author{
By Ikuzô URITANI** and Mark A. StahmanN*** \\ ** Laboratory of Biochemistry, Faculty of Agriculture, Nagoya University, Anjo; \\ ***Department of Biochemistry, University of Wisconsin, U.S.A. \\ Received February 23, 1961
}

\begin{abstract}
Tissue extracts of healthy, sliced and black-rotted sweet potato roots of several Japanese varieties showed immunochemical precipitation lines with antisera toward sliced and diseased tissue extracts prepared from an American resistant variety, Sunnyside. The immunochemical precipitation patterns of healthy and sliced tissue extracts and those of diseased tissue extract of the Japanese varieties respectively were almost the same as those of sliced and diseased tissue extracts of the American Sunnyside. Antigenic components designated as A and Cs were distributed in all tissue extracts of both Japanese and American varieties. Components $\mathbf{B}$ and $\mathbf{D}$ were produced in response to the infection in root tissues of Japanese varieties as well as of American ones. The amount of component B produced in several Japanese varieties was correlated with the magnitude of resistance action of root tissues to the fungus infection and the order was as follows: Norin No. 10 (highly resistant) $>$ Norin No. 1 and Okimasari (resistant) $>$ Norin No. 4 and Norin No. 5 (susceptible). Components B and D seemed to be present in healthy root tissue in very small amounts, and showed an increase in response to the simple injury or slicing, though the magnitude of this increase was much less than the response to the pathogenic infection.
\end{abstract}

\section{INTRODUCTION}

Our previous investigation indicated that certain antigenic components were produced in sweet potato root tissue in response to infection by Ceratocystis fimbriata ${ }^{1}$. In agargel precipitation experiments, two of these components showed intensive lines with antiserum toward a protein extract of non-infected root tissue adjacent to the injured region, and were designated as components $\mathbf{B}$ and $\mathbf{D}$. Enzymatic experiment has shown that component $\mathrm{D}$ is a peroxidase per se. Other anti-

* This is part 32 of a Study of Phytopathological Chemistry of Sweet Poato with Black Rot.

1) I. Uritani and M.A. Stahmann, Plant Physiol., in press. genic components were also found to be present in healthy and sliced tissues as well as in diseased tissues, and some of them were named components A, Cs, and Co. It was also found that the tissue adjacent to an infection site in Sunnyside, a typical resistant variety of American origin, produced an appreciably larger amonut of component $B$ than did Orange Little, a typical susceptible variety.

The present investigation is an extention of these experiments, using several sweet potato varieties of Japanese origin. An effort was made to determine whether there is any relationship between the amount of these antigenic components that are produced in tissue 
adjacent to the diseased tissue and the degree of host resistance.

\section{MATERIALS AND METHODS}

(1) Root Varieties and Treatment. Five varieties, Norin No. 1, No. 4 , No. 5 and No. 10 and Okimasari were selected for the present experiments. The resistance action of each variety toward the black rot fungus has been normally classified as follows: Norin No. 10 is highly resistant, Norin No. 1 and Okimasari are resistant, and Norin No. 4 and Norin No. 5 are susceptible. Roots of those varieties grown in the experimental farms of the Konosu National Agricultural Experiment Station and Toyohashi Agricultural Experiment Station of Aichi Prefecture were harvested in the autumn of 1959 , and sent to us in early spring of 1960 without being injured. They were stored at $10^{\circ} \mathrm{C}$ without fungal damage or noticeable sprouting. Individual roots were cut into three parts, one of which was subjected directly to extraction of the protein fraction without any innoculation or incubation, and this group is called "healthy tissue". The second group was sliced 2 to $3 \mathrm{~cm}$ thick, inoculated with spore suspension of C. fimbriata, and incubated at $30^{\circ} \mathrm{C}$ for 24 to 48 hours. Sections from the noninfected region ( 0.5 to $1.0 \mathrm{~mm}$ thick) just inside the injured region where the fungus grew were taken to extract the protein fraction. This group is called "diseased tissue". The third group is "sliced tissue" and the treatment was as follows: roots were sliced and incubated in the same way as in the second group, except there was no fungus inoculation. Sections 0.5 to $1.0 \mathrm{~mm}$ thick were taken from the tissue starting at the surface. The purpose of examining this group was to check the effect of slicing.

(2) Extraction of Proteins from Sweet Potato Tissues. Ten $g$ each of the above three different tissues were homogenized with $10 \mathrm{ml}$ of cold $0.05 \mathrm{M}$ phosphate buffer ( $\mathrm{pH} 7.5$ ) containing $12.5 \%$ glucose and $1 \%$ ascorbic acid in a homogenizer for $2 \mathrm{~min}$. Homogenate was filtered through four layers of cheese cloth, and filtrate was centrifuged at 9,000 r.p.m. for $20 \mathrm{~min}$. The supernatant was dialyzed for about 35 hours against 1 liter of the above phosphate buffer containing decreasing concentrations of ascorbic acid. The buffer was replaced four times; in the first and second dialyses ascorbic acid was $0.5 \%$, and in the third and the final steps it was $0.05 \%$. The dialyzate was stored in a frozen condition.

(3) Determination of Protein Nitrogen. Each tissue extract was mixed with trichloracetic acid solution, and the precipitated insoluble fraction was repeatedly washed with the same solution and dissolved in dilute sodium hydroxide; an aliquot was digested with sulfuric acid and asayed for nitrogen with Nessler's reagent.

(4) Preparation of Concentrated Antisera. The immunization technique was described in the previous paper ${ }^{1)}$. The rabbit antisera toward sliced and diseased tissue extracts of Sunnysidc were precipitated with one third saturated ammonium sulfate at the Department of Biochemistry, University of Wisconsin,. U.S.A. on January of 1960 , and the precipitated pellets were brought to this laboratory in Japan in an ice-cold state. For the present investigation condensed pellets were dissolved in $0.9 \% \mathrm{NaCl}$ of one third of the volume of the original antisera. It was dialyzed against $0.9 \%$. $\mathrm{NaCl}$, and stored in a frozen state until used.

(5) Antigen-antibody Test. The method based on the previous paper was as follows: $20 \mathrm{ml}$ of hot slurry of $1.2 \%$ agar solution containing $0.9 \% \mathrm{NaCl}$ and 20 $\mathrm{mg} \%$ merthiolate were spread on a Petri dish, and solidified on cooling. On this agar plate were made one hole $(8.3 \mathrm{~mm}$ in diameter) at the center and 6 other holes $(6.0 \mathrm{~mm}$ in diameter) at the distance of 1.8 to $2.0 \mathrm{~cm}$ from center in a symmetrical fashion (see Fig. 2). These holes were filled with antiserum and antigens, respectively. The dishes were placed in a moist chamber and incubated at $20^{\circ} \mathrm{C}$. The precipitation patterns were observed at regular intervals of 24 hours for about 5 days. Formation of a precipitation line by an antigen-antibody system represents an immunological positive reaction and its identity with a line formed by a different system can be visualized by the formation of continuous arc. Component $D$. was found to be a peroxidase and it was demonstrated that the enzymatic activity remained with the precipitation line formed by reaction with the antibody. Therefore, this property was applied to detect component $D$ as follows: after the immunological test, the Petri dish was immersed in a $0.9 \% \mathrm{NaCl}$ for 3 days: with several replacements of the solution to remove. that portion of component $\mathbf{D}$ not precipitated with the antibody. It was then sprayed with $1 \%$ pyrogallol, and after $1 \mathrm{~min} 1 \%$ hydrogen peroxide was applied. After several minutes the dish was immersed in $10 \%$. 
acetic acid to stop the reaction. A yellow brown color which formed on the line was taken as evidence of peroxidase activity, and was more easily observed than the precipitation line before the enzymatic coloration.

(6) Quantitative Analysis of Antigens with Immunochemical Absorption. Quantitative estimation of a particular antigenic component present in each tissue extract was carried out according to the quanti- tative serum-agar technique of Wright ${ }^{2)}$. One part of the concentrated antiserum toward diseased tissue extract of Sunnyside was mixed with 1 part of a serial dilution of solution (1 (original) , 3, 7.5, 15, 30 and 60 ) of a tissue extract of each variety and was left in an ice box. After two days, the diseased tissue extract of Norin No. 1 (Toyohashi) was put into the central hole as a standard antigen, and the above

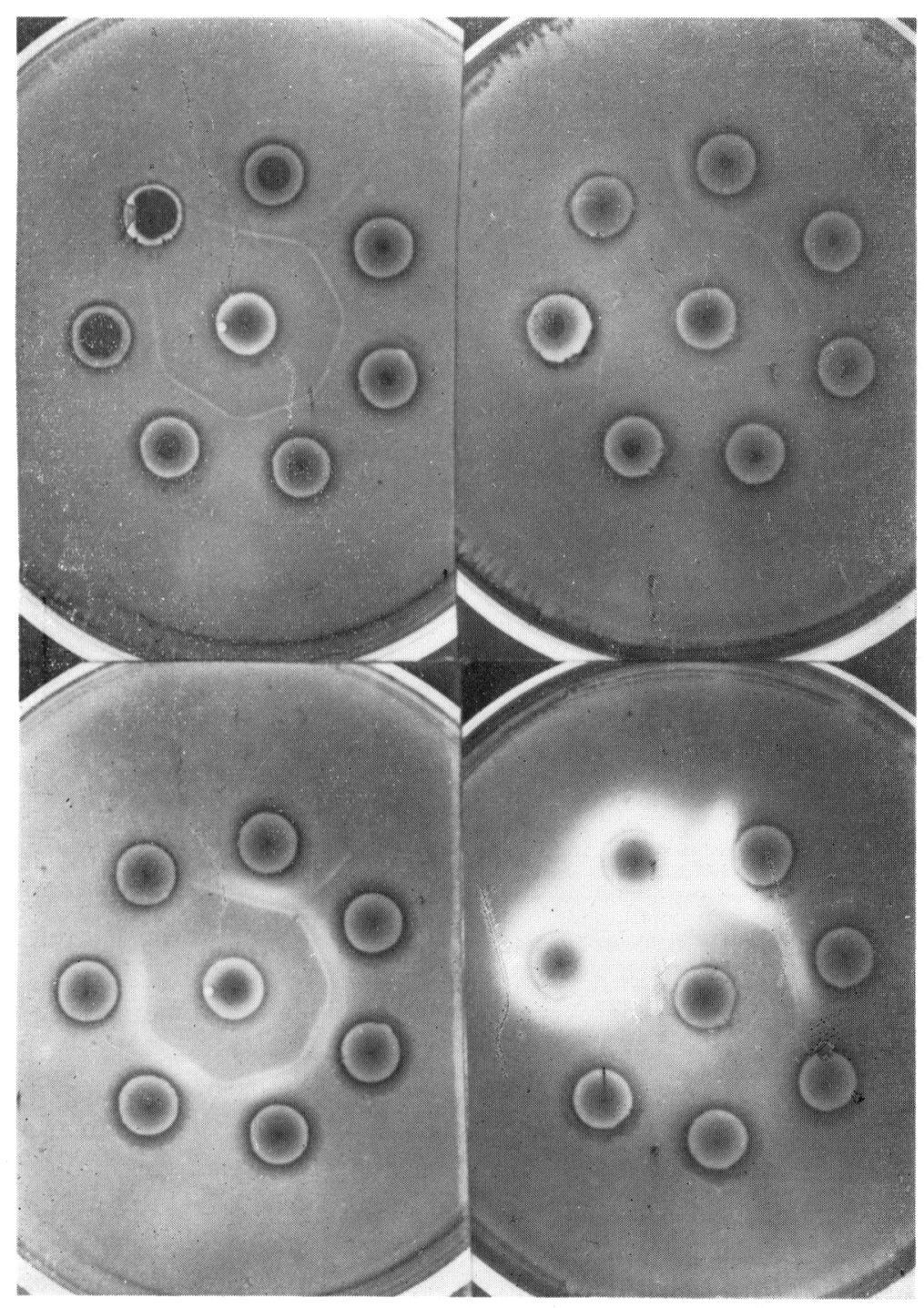

FIG. 1. (a)

2) S.T.C. Wright, Nature, 183, 1282,1959$)$. 


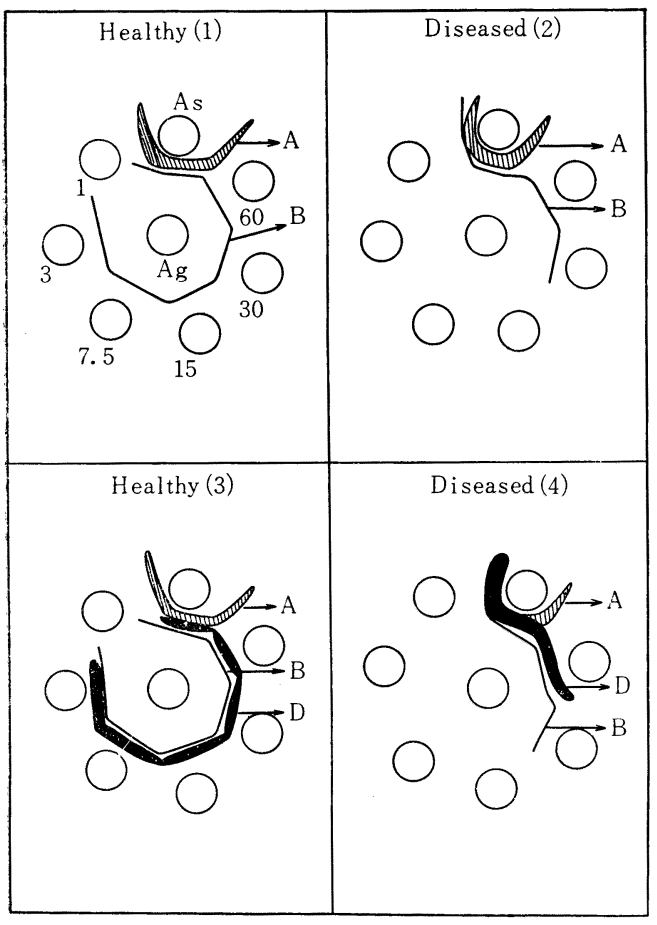

FIG. 1. (b)

FIG. 1. Quantitative Analysis for Antigens by Immunochemical Absorption

(a): Photographs

(b): Drawings according to (a)

Healthy and Diseased: Absorption of antibodies in antiserum toward diseased tissue extract of Sunnyside with antigens in healthy and diseased tissue extracts of Norin No. 10 (Konosu ', respectively.

(1) and (2): Patterns before purpurogallin formation by the peroxidase activity of component D.

(3) and (4): Patterns after purpurogallin formation.

$\mathrm{Ag}$ and As: Diseased tissue extract of Norin No. 1 (Toyohashi) as a standard antigen (Ag) and antiserum (As) toward diseased tissue extract of Sunnyside.

$1,3,7.5,15,30$ and 60 : The dilution values of healthy or diseased tissue extract of Norin No. 10 (Konosu). A mixture at the indicated dilution plus a constant volume of antiserum toward diseased tissue extract of Sunnyside (1:1) was put in to each outer hole after 2 day incubation in cold.

mixtures of varied tissue extract concentration plus antiserum, and antiserum per se were put into the surrounding 7 holes. After 5 days of incubation, the precipitation lines were isvestigated. When there is no amount of a particular antigenic component (or very little) in a tissue extract, then the corresponding antibody in the antiserum is not absorbed during the storage period and a continuous arc precipitation line should appear between the standard antigen (extract) - mixture systems and the standard antigen (extract)anticerum. If, on the other hand, an appreciable amount of the antigenic component is present in a tissue extract, the antibody in the antiserum should be absorbed on mixing, thus a specimen which had abzorbed all the specific antibody in certain volume of the anticerum can not give a precipitation line in the agar plate. Quantitative estimation of a particular an:igenic comopnent in a tissue extract was expressed as the range between the minimum amount of a tissue extract abzorbing all the antibody and maximum amount of the extract which did not absorb all the antibody. Such amounts were expressed as the dilution value of the antigenic extract required to reach this range. In case the precipitation line was very faint, estimation was expressed as that amount (dilution value) of the extract. The quantity of component $D$ was estimated after intensification of the precipitation line by the yellow brown color which formed from pyrogallol following peroxidase action. Those processes are diagramatically presented in Fig. 1, which shows the degree of antibody absorption by components $\mathrm{A}, \mathrm{B}$ and $\mathrm{D}$ in healthy and diseased tissue extracts of Norin No. 10 (Konosu). The quantitative amount of each component was calculated from each pattern, and the dilution values which represent the relative amount of each antigen are given in Experiment (2) of Table I.

\section{RESULTS}

(1) Infection Symptoms and Magnitude of Host Resistance.

The relative resistance action of root tissue from different varieties toward the black rot fungus was in agreement with the previous observations of ours ${ }^{3}$ and of Mori ${ }^{4}$ and follows in decreasing order: Norin No. 10> Norin No. 1 and Okimasari $>$ Norin No. 4 and Norin No. 5. Generally speaking, the following changes or biochemical symptoms characterize the typical resistance action of the infected root tissue: (a) an intense browning in the injured part, (b) a thin layer of injured tissue, (c) a marked disturbance of the formation of aerial hyphae and perithecia and (d)

3) I. Uritani and T. Akazawa, Kagaku (Tokyo), 25, 614 (1955).

4) K Mori, Report of Dept. of Plant Pathol., the Konosu Natl. Agr. Expt. Station (1959; 
an intense pink coloration in the injured part by reaction of ipomeamarone and other similar components with Ehrlich's reagent $(10 \%$ p-dimethylaminobenzaldehyde in $40 \mathrm{vol} . \%$ sulfuric acid). The symptoms following infection of Norin No. 1, Norin No. 10 and Okimasari all satisfied those resistance features, among which the reaction of Norin No. 10 was the strongest. Norin No. 4 and Norin No. 5 showed a less marked resistance action, and was considered to be rather susceptible as compared with the above resistant varieties. (2) Immunochemical Precipitation Pattern.

Healthy, sliced and diseased tissue extracts of Norin No. 1 showed in agar gel two major precipitation lines with the antiserum toward sliced tissue extract of Sunnyside, and each of these lines formed a continuous arc with two lines formed by components $\mathrm{A}$ and $\mathrm{Cs}$ in sliced tissue extract of Sunnyside. Thus,

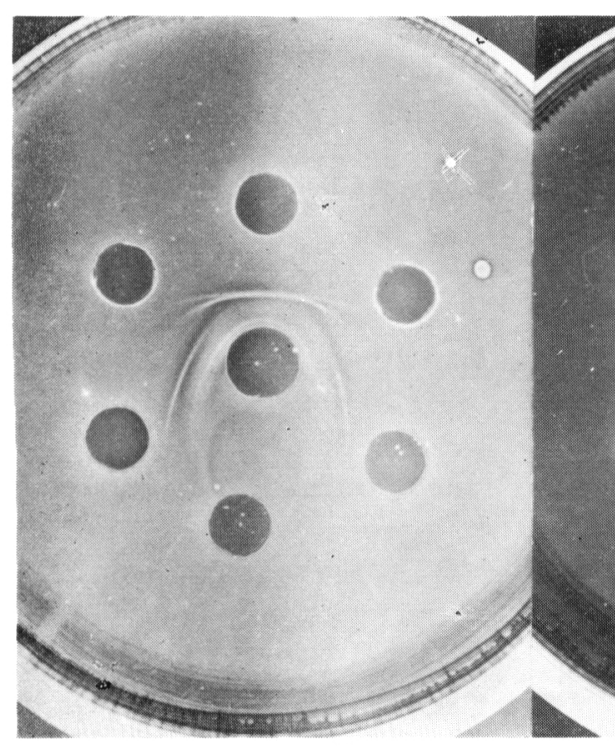

FiG. 2. (a)

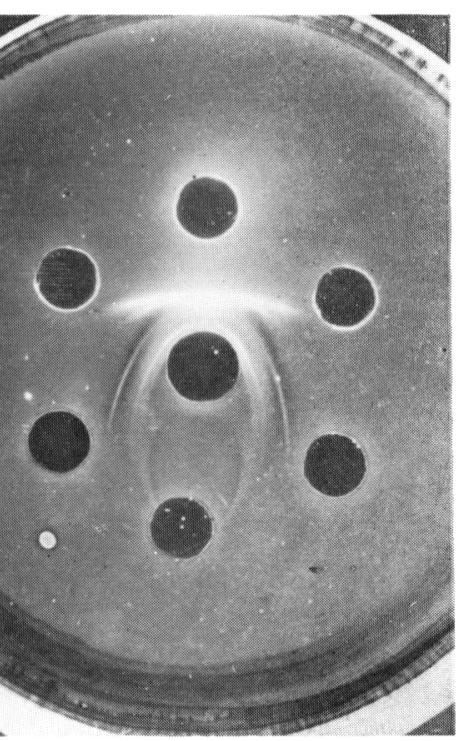

FIG. 2. (b)

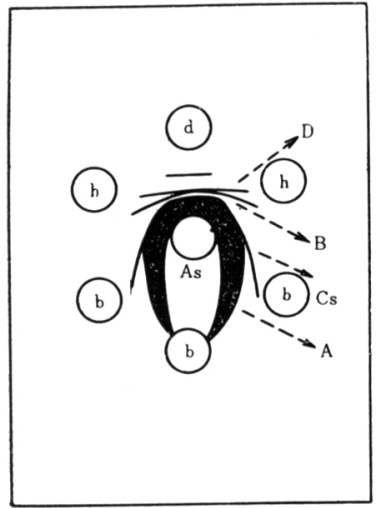

FIG. 2. Precipitation Patterns Occurring between Tissue Extracts of Norin No. 1 and Antiserum toward Diseased Tissue Extracts of Sunnyside

(a): Precipitation patterns shown by a photograph.

(b): Intensification of the pattern of component D by purpurogallin formation.

(c): Drawing according to (a).

As: Antiserum toward diseased tissue extract of Sunnyside.

$h$ and $d$ : Healthly and diseased tissue extracts of Norin No. 1 (Toyohashi).

b: $0.05 \mathrm{M}$ phosphate buffer $(\mathrm{pH} 7.5)$.

A, B, Cis and D: Antigenic components found first in tissue extracts of Sunnyside.

FIG. 2. (c) 
components $\mathrm{A}$ and $\mathrm{Cs}$ were found to be uniformly present in every tissue extract of Norin No. 1 as well as in extract of Sunnyside. The previous investigation showed that diseased tissure extract of Sunnyside contains two other immunologically specific components called B and D. Diseased tissue extract of Norin No. 1 also gave two additional lines besides $\mathrm{A}$ and $\mathrm{Cs}$ with the antiserum toward diseased tissue extract of Sunnyside (Fig. 2(a), (c)). Based on the comparative examination with the immunological pattern of diseased tissue extract of Sunnyside, these two lines were proved to be immunochemically identical with component $\mathrm{B}$ and D. Component $\mathrm{D}$ is a peroxidase and retains some enzymatic activity after the immunochemical reaction. Fig. 2-(b) shows the intensification of the precipitation line of component $\mathrm{D}$ in diseased tissue extract of Norin No. 1 by such enzymatic treatment. The similar results were obtained also in experiment using root tissues of other varieties.

(3) Quantitative Estimation of Components A, B and $D$ by the Immunological Method.

As shown in Table I, components B and D were produced in the tissue of every variety, on exposure to the infection or on slicing. However, the rate of production due to slicing was much less than that following fungus infection. The amount of component $B$ in diseased tissue appears to be roughly parallel to the magnitude of the resistance action of the host tissue and was in the following order: Norin No. 10 (highly resistant) $>$ Norin No. 1 and Okimasari (resistant) $>$ Norin No. 4 and Norin No. 5 (susceptible). The production of component $\mathrm{D}$ in diseased tissue of Norin No. 10 was much larger than that in other varieties, which had no appreciable difference. Both components $\mathrm{B}$ and $\mathrm{D}$ were found to be present in healthy tissue itself, though their amount was very small. No appreciable difference has been observed, in the production
Table I. The Amounts of Antigenic Compounds and PRotein Nitrogen in Tissue Extracts

\begin{tabular}{|c|c|c|c|c|c|c|}
\hline \multirow{2}{*}{$\begin{array}{l}\text { Experi- } \\
\text { ment }\end{array}$} & \multirow{2}{*}{\multicolumn{2}{|c|}{ Tissue }} & \multicolumn{3}{|c|}{ Antigenic compont } & \multirow{2}{*}{$\begin{array}{l}\text { Protein } \\
\text { nitrogen } \\
(r / \mathrm{ml})\end{array}$} \\
\hline & & & A & B & $(\gamma$ & \\
\hline \multirow[t]{5}{*}{ (1) } & No. $1(\mathrm{~T})$ & $\begin{array}{l}\mathrm{H} \\
\mathrm{D}\end{array}$ & $\begin{array}{l}>60 \\
>60\end{array}$ & $\begin{array}{l}<1 \\
7.5\end{array}$ & $\begin{array}{l}<1 \\
7.5 \sim 15\end{array}$ & $\begin{array}{l}435 \\
600\end{array}$ \\
\hline & No. $1(\mathrm{~T})$ & $\begin{array}{l}\mathrm{H} \\
\mathrm{S} \\
\mathrm{D}\end{array}$ & $\begin{array}{l}>60 \\
>60 \\
>60\end{array}$ & $\begin{aligned}<1 \\
<1 \\
3 \sim 7.5\end{aligned}$ & $\begin{array}{l}<1 \\
1 \sim 3 \\
7.51 \sim 5\end{array}$ & $\begin{array}{l}280 \\
500 \\
505\end{array}$ \\
\hline & No. $4(\mathrm{~T})$ & $\begin{array}{l}\mathrm{S} \\
\mathrm{D}\end{array}$ & $\begin{array}{l}1 \sim 3 \\
1 \sim 3\end{array}$ & $\begin{array}{l}<1 \\
3\end{array}$ & $\begin{array}{l}1 \sim 3 \\
7.5 \sim 15\end{array}$ & $\begin{array}{l}224 \\
298\end{array}$ \\
\hline & No. $5(T)$ & $\begin{array}{l}\mathrm{H} \\
\mathrm{S} \\
\mathrm{D}\end{array}$ & $\begin{array}{l}30 \sim 60 \\
30 \sim 60 \\
30 \sim 60\end{array}$ & $\begin{array}{l}<1 \\
<1 \\
1 \sim 37\end{array}$ & $\begin{array}{l}1 \\
1 \sim 3 \\
7.5 \sim 15\end{array}$ & $\begin{array}{l}205 \\
295 \\
245\end{array}$ \\
\hline & No. $10(\mathrm{~T})$ & $\begin{array}{l}S \\
D\end{array}$ & $\begin{aligned} & >60 \\
30 & \sim 60\end{aligned}$ & $\begin{array}{c}1 \sim 3 \\
7.5 \sim 15\end{array}$ & $\begin{array}{c}1 \sim 3 \\
15 \sim 30\end{array}$ & $\begin{array}{l}335 \\
470\end{array}$ \\
\hline \multirow[t]{4}{*}{$(2)$} & No. $4(\mathrm{~T})$ & $\begin{array}{l}\mathrm{H} \\
\mathrm{S} \\
\mathrm{D}\end{array}$ & $\begin{array}{l}1 \sim 3 \\
1 \sim 3\end{array}$ & $\begin{array}{l}1 \\
1 \sim 3 \\
3 \sim 7.5\end{array}$ & $\begin{array}{l}1 \sim 3 \\
3 \sim 1.5 \\
53 \sim 7.5\end{array}$ & $\begin{array}{l}165 \\
300 \\
375\end{array}$ \\
\hline & No. $5(\mathrm{~T})$ & $\begin{array}{l}\mathrm{S} \\
\mathrm{D}\end{array}$ & $\begin{array}{l}3 \sim 7.5 \\
3 \sim 7.5\end{array}$ & $\begin{array}{l}<1 \\
1 \sim 3\end{array}$ & $\begin{array}{l}1 \sim 3 \\
3 \sim 7.5\end{array}$ & $\begin{array}{l}179 \\
188\end{array}$ \\
\hline & No. 10 K & $\begin{array}{l}\mathrm{H} \\
\mathrm{S} \\
\mathrm{D}\end{array}$ & $\begin{array}{l}>60 \\
>60 \\
>65\end{array}$ & $\begin{array}{c}1 \sim 3 \\
7.5 \\
15 \sim 30\end{array}$ & $\begin{array}{c}1 \sim 3 \\
1 \sim 3 \\
30 \sim 60\end{array}$ & $\begin{array}{l}815 \\
715 \\
823\end{array}$ \\
\hline & No. $10(\mathrm{~T})$ & $\begin{array}{l}\mathrm{H} \\
\mathrm{D}\end{array}$ & $\begin{array}{c}>60 \\
30 \sim 60\end{array}$ & $\begin{array}{c}1 \sim 3 \\
7.5 \sim 15\end{array}$ & $\begin{array}{l}<1 \\
15 \sim 30\end{array}$ & $\begin{array}{l}466 \\
480\end{array}$ \\
\hline \multirow[t]{3}{*}{ (3) } & No. $1(\mathrm{~K})$ & $\begin{array}{l}\mathrm{S} \\
\mathrm{D}\end{array}$ & $\begin{array}{l}30 \sim 60 \\
30 \sim 60\end{array}$ & $\begin{array}{c}1 \sim 3 \\
7.5 \sim 15\end{array}$ & $\begin{array}{c}1 \sim^{3} \\
15\end{array}$ & $\begin{array}{l}308 \\
360\end{array}$ \\
\hline & $\begin{array}{l}\text { Okimasari } \\
(\mathrm{K})\end{array}$ & $\begin{array}{l}\mathrm{S} \\
\mathrm{D}\end{array}$ & $\begin{array}{l}>60 \\
>60\end{array}$ & $\begin{aligned} & 3 \sim 7.5 \\
7.5 & \sim 15\end{aligned}$ & $\begin{array}{l}51 \sim 3 \\
7.5 \sim 15\end{array}$ & $\begin{array}{l}365 \\
568\end{array}$ \\
\hline & No. $10(\mathrm{~K})$ & $\begin{array}{l}H \\
S_{1} \\
S_{3} \\
D_{i} \\
D_{2}\end{array}$ & $\begin{array}{l}>60 \\
>60 \\
>60 \\
>60 \\
>60\end{array}$ & $\begin{aligned}<1 \\
1 \sim 3 \\
3 \sim 7.5 \\
7.5 \sim 15 \\
30 \sim 60\end{aligned}$ & 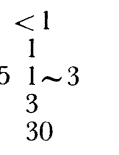 & $\begin{array}{r}870 \\
697 \\
605 \\
605 \\
1050\end{array}$ \\
\hline
\end{tabular}

$\mathrm{H}, \mathrm{S}$ and $\mathrm{D}$ : Healthy, sliced and discased tissue extracts $\mathrm{S}_{1}, \mathrm{~S}_{2}, \mathrm{D}_{1}$ and $\mathrm{I}_{2}$ : Extracts of sliced and diseased tissues after 1 and 2 day incubations, respectively.

(K) and (T): The roots sent from Konosu Agricultural Fxperiment station and Toyohashi Agricultural Experiment Station of Aichi Prefecture, respectively.

of these two components in response to the slicing among these varieties. However, the formation of component $\mathbf{B}$ seemed to be slightly higher in Norin No. 10. A daily increase of both components $\mathrm{B}$ and $\mathrm{D}$ was quite evident in diseased tissue and also in sliced tissue.

The amount of component $\mathrm{A}$ was not appreciably changed by either infection or slicing except for three cases in which its amount was decreased in response to the infection. These were Norin No. 10 at experiments (1) and (2) and Norin No. 4 at experiment (2) 
of Table I. The amount of component $\mathrm{A}$ in Norin No. 1, Norin No. 10 and Okimasari was much higher than in Norin No. 4 and Norin No. 5.

The quantities of protein nitrogen in the tissue extracts are also recorded in Table $I$. There was not a great difference between sliced and diseased tissues. However, the amount of protein in healthy tissue was low$\mathrm{er}$ in some cases. Therefore, the immunological activity of each antigenic component based on the protein nitrogen gives a similar picture to that presented in Table I which has been expressed on a fresh weight basis.

\section{DISCUSSION}

It is worthwhile to note that several antigenic components designated $\mathrm{A}$, and $\mathrm{Cs}$ were present in every tissue extract of the American varieties, Sunnyside and Orange Little, and were also found to be present in tissue extracts of all five Japanese varieties which were examined in the present experiments. Thus, those antigenic components were believed to be uniformly distributed or produced in all varieties of sweet potatoes, Ipomea batatatis.

Components B and D were found to be produced in root tissue in response to the infection in the Japanese varieties as well as in the American varieties. The rate of production of comopnent $\mathrm{B}$ in diseased tissues of the several Japanese varieties was roughly parallel to the magnitude of their resistance action toward the black rot fungus. This fact is in agreement with our previous experiment using sweet potato varieties of American origin $^{1}$. Production of component D was greatest in the diseased tissue of Norin No. 10, a highly resistant variety, but the exact relationship between the rate of its formation and the magnitude of host resistance of five varieties has not been clear. More detailed analysis should be made before a final conclu- sion on this problem is obtained. Enzymatic entity of component $\mathrm{D}$ has been identified as a peroxidase, by its enzymatic action. Its specific location on the starch gel electrophoresis ${ }^{1)}$ will enable to assay more quantitatively this particular component.

There have been established two typical post-infectional metabolic changes in sweet potato roots; the first is the augmented respiratory rate in the non-infected tissue adjacent to the injured region, and the second is the formation of ipomeamarone in the injured tissue. Our previous experiment has also shown that the rate of those two metabolic events parallel the magnitude of host resistance ${ }^{3,5,6)}$. In our present immunochemical studies, it is now established that the formation of component $\mathbf{B}$ is a third parameter which is induced by the infection and its formation appears to be parallel to the magnitude of resistance. Clarification of the nature of component $\mathrm{B}$ and the interrelationship among those three different factors, respiratory rate, ipomeamarone formation and component $\mathrm{B}$ production may lead to a better clue to understanding of the mechanism of resistance.

Trace amounts of components $\mathbf{B}$ and $\mathbf{D}$ were found to be present in healthy tissue and to increase following simple slicing. This implies that these two components are synthesized in root tissue as a general response to tissue destruction and not as a specific response to the pathogenic infection by $C$. fimbriata. However, it should be emphasized that the metabolic alterations induced by the slicing are not exactly identical with that due to the infection. For instance, the quantities of components $\mathrm{B}$ and $\mathrm{D}$ in sliced tissue extracts were about one seventh that in diseased tissue extracts. On the contrary, the augmented

5) I. Uritani and T. Akazawa, "Plant Pathology" (J.G, Horsfall and A.E Dimond, eds.), Academic Press, New York, Vol 1, 1959, p. 349.

6) T. Akazawa and K. Wada. Plant Physiol., 36, in press (1961). 
respiratory rate and the increased total activity of peroxidase does not show much difference between those two tissues; furthermore the electrophoric pattern of peroxidase on starch gel was somewhat different for sliced and diseased root tissues ${ }^{7)}$. It would be of great value to investigate further the mechanism of metabolic alterations responding to the pathogenic infection from the comparative aspect of both equality and diversity of

7) I. Uritani, N. Kawashima, K. Akutsu and T. Akazawa, Abstract, of Ann. Meeting Agr. Chem. Soc. Japan, (1961). metabolic systems in diseased and sliced tissues.

Acknowledgement We wish to express our thanks to Dr. K. Mori, the Konosu National Agricultural Experiment Station and Dr. T. Tokunaga, the Toyohashi Agricultural Experiment Station of Aichi Prefecture for their providing us sweet potato roots for this experiments, to Dr. T. Akazawa for his helpful discussions, and to Mrs. H. Nomura for her technical assistance. 